\title{
RELIGIOUS MODERATION AS THE INITIAL EFFORT TO FORM TOLERANCE ATTITUDE OF ELEMENTARY SCHOOL
}

\section{MODERASI BERAGAMA SEBAGAI UPAYA AWAL PEMBENTUKAN SIKAP TOLERANSI SISWA SEKOLAH DASAR}

\author{
Sunarti ${ }^{1}$, Dwivelia Aftika Sari ${ }^{2}$ \\ ${ }^{1}$ Pendidikan Guru Madrasah Ibtidaiyah IAIN Batusangkar, ${ }^{2}$ Tadris Kimia IAIN Batusangkar \\ ${ }^{1,2}$ Jl. Jenderal Sudirman No.137, Limo Kaum, Lima Kaum, Kabupaten Tanah Datar, \\ Sumatera Barat 27217 \\ Email: sunarti@iainbatusangkar.ac.id ${ }^{1}, \underline{\text { dwiveliaaftikasari@ iainbatusangkar.ac.id }}^{2}$
}

Submitted: 11-09-2021, Revised: 07-11-2021, Accepted: 18-11-2021

\begin{abstract}
As social beings living in a pluralistic environment, a moderate attitude is needed to create tolerance between existing differences. It is necessary to realize the cultivation of religious moderation in education to get a moderate understanding. Religious moderation needs to be instilled not only in universities but also at the elementary school level to create student tolerance from an early age. This study aims to determine the tolerance attitude of elementary school students like what is formed by cultivating the value of religious moderation. The research types were field research and library research. The population of this study was students of SDN 010 Simpang Petai Village, with 94 students as the sample from the high class, namely grades 4,5 , and 6 . The field research findings showed that the tolerance attitude of SDN 010 students in Simpang Petai Village in the peace aspect was at $30 \%$, the respect for differences and individuals was at $25 \%$, and the awareness aspect was at $18 \%$. This result indicated that the tolerance attitude of students was in a bad category. Then, the field data results became a reference for conducting library research that this religious moderation was realized through character education: value inculcation, cognitive moral development, value analysis, value clarification, and learning to action approaches. In this way, student tolerance would be formed, namely religious tolerance, thought tolerance, social tolerance, and racial tolerance in elementary school students.
\end{abstract}

Keywords: Elementary School Students, Religious Moderation, Tolerance Attitude

\section{Abstrak}

Sebagai makhluk sosial yang hidup di lingkungan yang majemuk maka sangat dibutuhkan sikap yang moderat agar terciptanya toleransi antar perbedaan yang ada. Untuk sampai kepada pemahaman yang moderat, maka dibutuhkan realisasi penanaman paham moderasi beragama dalam dunia pendidikan. Moderasi beragama perlu ditanamkan tidak hanya ditingkat perguruan tinggi, tapi juga sekolah dasar agar terciptanya sikap toleransi siswa dari sejak dini. Penelitian ini bertujuan untuk mengetahui sikap toleransi siswa sekolah dasar seperti apa yang terbentuk melalui penanaman nilai moderasi beragama. Jenis penelitian ini adalah penelitian lapangan (field research) dan jenis penelitian kepustakaan (library research). Adapun papulasi dari penelitian ini adalah siswa SDN 010 Desa Simpang Petai dengan sampel adalah kelas tinggi yaitu kelas 4, 5, dan 6 berjumlah 94 orang. Adapun hasil penelitian lapangan yaitu ditemukan sikap toleransi siswa SDN 010 Desa Simpang Petai pada aspek kedamaian berada di angka 30\%, aspek mengahargai pebedaan dan individu berada pada angka 25\% dan pada aspek kesadaran diangka 18\%, hal ini menunjukkan bahwa sikap toleransi siswa berada pada kategori buruk. Hasil data lapangan menjadi acuan untuk melakukan penelitian kepustakaan bahwa moderasi beragama ini direalisasikan melalui pendidikan karakter yaitu, pendekatan penanaman nilai, pendekatan perkembangan moral kognitif, pendekatan analisis nilai, pendekatan klarifikasi nilai, dan 
pendekatan pembelajaran berbuat, sehingga terbentuk sikap toleransi siswa yaitu toleransi beragama, toleransi pemikiran, toleransi sosial, dan toleransi rasial pada siswa sekolah dasar.

Kata Kunci: Siswa Sekolah Dasar, Moderasi Beragama, Sikap Toleransi

How to Cite: Sunarti, \& Sari, D. A. (2021). Religious Moderation as the Initial Effort to Form Tolerance Attitude of Elementary School. AULADUNA: Jurnal Pendidikan Dasar Islam, 8(2), 138-149.

\section{Introduction}

Currently, we are in a country rich in natural and human resources, namely Indonesia. Not only abundant natural resources, but Indonesia is also known as a multicultural country in terms of ethnicity, lifestyle, language, and belief. This diversity is a factor of plurality for Indonesian, and this is a wealth of Indonesian nature that we should be grateful for. With the diversity, we use it as our reinforcement and our unifier as citizens of Indonesia. This plurality gave birth to a motto that became a meeting point for all Indonesian people, namely "Bhineka Tunggal Ika" although different but still united in the unity of the Indonesian State.

But in reality, the existing pluralism sometimes causes conflicts and even clashes between tribes and beliefs. At the same time, plurality in Indonesia is a natural gift from God. Accepting these conditions is necessary to create a unitary state and become an "integrating force" in our daily lives. This diversity has been explained in the Qur'an 49:13 that "We made you into nations and tribes so that you may know each other." Understanding these differences is often not by the actions that occur. Conflicts are still found caused by differences in ethnicity, culture, and belief.

Compared to culture, conflicts of belief are more common in Indonesia. One of them is the conflict in Poso involving Islam and Christian (Alganih, 2016: 167). It is an example of a conflict that occurred in religion in 1998. Examples of the simplest cases we often encounter in our daily environments include laughing at each other's culture and beliefs. Other examples are also found during the current pandemic. Some people do not approve policies from the government on health protocols. This situation can be seen from their unwillingness to comply with the rules that have been set. It is a form of action contrary to the moderate attitude in realizing a United State.

It is certainly a concern for all of us to instill the values of moderation in every aspect of life, especially in the religious element, provide education, and understanding regarding religious moderation to every aspect of life. Al-Qaradawi in Aziz \& Najmudin (2020: 97-98) said that religious moderation is a middle position between two opposing extreme parties. Taking a stance through this middle way is called moderation and must be instilled in every individual. In providing education related to religious moderation, education is one of the right ways. The realization of religious moderation in education prepares a generation with a high tolerance attitude. Tolerance is defined as an attitude of being open-minded and respectful toward diversity, regardless of people's ethnic, social backgrounds, or lifestyles they have preferred (Alhendi, 2021: 101). Tolerance means respecting, allowing, letting other opinions, views, beliefs, habits, behavior, or those contrary to the founder himself (Ndolu \& Tari, 2020: 77).

But in reality, religious moderation does not touch all education levels. Education about religious moderation is more dominant in universities, starting at the most basic level. Because intolerance also occurs in the elementary school environment with conflicts that occur according to their age, the color of the understanding of religious moderation is also following their cognitive level and psychological development. 
Elementary school age is a developmental age that responds well to all aspects of life outside of itself. As the opinion expressed by (Amran, Sahabuddin, \& Muslimin, 2018: 255) that elementary school age is an age that can imitate concrete behavior every time they see, so it is very useful for character building. Not only that, children's curiosity at this stage is very high, so it is possible if religious moderation is instilled in them from an early age and this religious moderation is adjusted to their development level.

The weak level of tolerance among elementary school students was found at SDN 010 Simpang Petai in high grade, and the tolerance attitude of students towards friends and teachers was at $30 \%$. This figure was still in the poor category, where the tolerance level of elementary school students should be above the poor category, because considering that this elementary school period was the initial formation of student identity. It could be seen from the tolerance indicators used in the research questionnaire. The indicators were: peaceful being amid differences, being open and responding well to differences with friends and other people, respecting other people of different religions, respecting other people with different backgrounds, caring for others from different religions, being unafraid of others who are different from himself, loves and cares for people who have differences with himself, respects the goodness of his/her friends and others, respects the work of his/her friends and others, and respects the thoughts or opinions of his/her friends and others.

Based on the above explanation, the author would like to explain in this paper regarding religious moderation as an initial effort to form a tolerance attitude of elementary school students. Thus, cultivating religious moderation would provide the main capital in preparing elementary school students to have an early tolerance attitude.

\section{Research Method}

The types of research used were field research and library research. Field research was carried out because the study was developed through interpretation using the data found at the research site. The library technique was library research carried out by reading, studying, and recording various literature or reading materials by the subject matter, which was then filtered and poured into a theoretical framework of thought. This research method aimed to get data by reviewing texts, reference books, and publications that answered the discussed problem. In this study, the author wanted to examine matters relating to religious moderation as an initial effort to form tolerance attitudes of elementary school students.

Sari \& Asmendri (2020: 45) said literature research collected, read, and recorded literature/books. For this reason, this study was taken from various sources as literary texts relevant to the field of study. The data sources used were the results of previous studies relevant to the topics discussed. The first step in this research was to collect various references or library data, then read, record, analyze, and compare the literature found to be processed to conclude as a result of this research. This study took secondary data from scientific journals, textbooks, and literature reviews that examined the same topic. This research was a needs analysis research in a thoughtful contribution. It could be used as a basis for personality to add insight regarding religious moderation at the elementary school level. This study aimed to produce an in-depth theoretical study related to the formation of student tolerance in elementary schools by cultivating the value of religious moderation, which was analyzed through data obtained in the field. 


\section{Results and Discussion}

In a broad sense, tolerance is a human behavior or attitude that does not deviate from the rules where everyone respects their differences. This tolerance is one of the building blocks of a peaceful life, but not everyone has this tolerant attitude. Then what kind of tolerance should be formed in the lives of elementary school students? and what is the form of planting the value of religious moderation so that tolerance is formed? (Supriyanto \& Wahyudi, 2017: 65). There are several indicators of tolerance that can be seen from elementary school students:

Table 1. Tolerance Indicator

\begin{tabular}{ll}
\hline \multicolumn{1}{c}{ Aspects of Tolerance } & \multicolumn{1}{c}{ Indicators } \\
\hline Peace & a. Care \\
& b. Fearlessness \\
& c. Love \\
\hline Respecting Differences and Individuals & a. Respect each other \\
& b. Appreciate the differences of others \\
& c. Appreciate themselves \\
\hline Awareness & a. Appreciate the kindness of others \\
& b. Open \\
& c. Receptive \\
& d. Comfort in life \\
& e. Comfort with others \\
\hline
\end{tabular}

Based on the results of the questionnaire that was distributed at SDN 010 Simpang Petai Village, it was found that:

Table 2. Results of the Student Tolerance Questionnaire of SDN 010 Simpang Petai Village

\begin{tabular}{lc}
\hline \multicolumn{1}{c}{ Aspects of Tolerance } & Percentage \\
\hline Peace & $30 \%$ \\
\hline Respecting Differences and Individuals & $25 \%$ \\
\hline Awareness & $18 \%$ \\
\hline
\end{tabular}

From the questionnaire results, a literature analysis was carried out by seeking to inculcate the value of religious moderation for the formation of tolerance attitudes of elementary school students. Moderation is an attitude that is not excessive towards something and does not tend towards one party. Someone with a moderate attitude will act in the middle line without fanaticism or resistance to something. We should apply this moderate attitude in various aspects of life and the most important thing is the diversity of beliefs in Indonesia because there are several recognized religions. This condition requires us to be moderate and balance our beliefs and others' beliefs without being extreme and fanatic. This is called religious moderation. Sutrisno (2019: 330) said that understanding religious moderation is a religious attitude that is balanced between one's own experience (exclusive) and respect for the religious practices of other people with different beliefs (inclusive). The respect we give to the beliefs of others is also known as tolerance.

An understanding of religious moderation will give birth to a peaceful life, and without this understanding, there will be conflicts and clashes. Religious moderation 
puts forward brotherhood based on humanity, so this understanding of religious moderation needs to be developed and instilled at every level of education to create a harmonious life. Agus in Akhmadi (2019: 54) also stated that the concept of moderation (al-wasathiyah) is capital in building harmony. Such is the importance of religious moderation in daily life to build tolerance for each individual.

Cooperation from various groups is needed in realizing a moderate society, and one of the forums for religious moderation is education. Because education is the biggest center in developing knowledge, attitudes, and skills. This is also stated in the national education goal to produce a generation of noble character. Preparing students to have this tolerance attitude, starts from the basic level, namely at the elementary school level.

Elementary school students are children aged between 6-12 years, also called the intellectual period. Children's knowledge develops at this age. Children's knowledge increases with age; the cognitive, affective, and psychomotor aspects that are mastered will be more diverse as their age develops. At this age, children's interests focus on all dynamically moving forms. It implies that children tend to carry out various activities useful in their future development. Intellectually elementary school age has a great interest in learning and skills. However, students are divided into low-grade and highgrade elementary school students (Sudarmawan, 2013). Elementary school-age is divided into low grades (1,2, and 3) and high-grade students (grades 4,5 and 6). The characters of elementary school students in low and high grades can be seen in the following table:

Table 3. Characters of Low and High-Grade Elementary School Students

\begin{tabular}{|c|c|}
\hline Level & Characters \\
\hline $\begin{array}{l}\text { Low Grades }(1,2 \text {, and } 3) \text { of } \\
\text { Elementary School }\end{array}$ & $\begin{array}{l}\text { 1. There is a high positive correlation between the two } \\
\text { health of physical growth and school achievement } \\
\text { 2. There is a tendency to praise oneself } \\
\text { 3. They like to compare themselves with other children } \\
\text { 4. At this time, especially at the age of 6-8 years, } \\
\text { children want good grades (score report) without } \\
\text { remembering whether their achievements deserve } \\
\text { good grades or not } \\
\text { 5. Subject to the rules of the game that exist in the } \\
\text { world } \\
\text { 6. If they cannot solve a problem, the question is } \\
\text { considered unimportant }\end{array}$ \\
\hline $\begin{array}{l}\text { High Grades }(4,5 \text {, and } 6) \text { of } \\
\text { Elementary School }\end{array}$ & $\begin{array}{l}\text { 1. There is an interest in concrete and practical } \\
\text { everyday life } \\
\text { 2. Realistic, have curiosity, and want to learn } \\
\text { 3. Towards the end of this period, there has been an } \\
\text { interest in special things or subjects } \\
\text { 4. At the age of } 11 \text { years, children need teachers or } \\
\text { other adults to complete their tasks and fulfill their } \\
\text { desires. After } 11 \text { years, children generally face their } \\
\text { tasks freely and try to complete them on their own } \\
\text { 5. At this time, children view grades (score report) as } \\
\text { an appropriate measure of school achievement }\end{array}$ \\
\hline
\end{tabular}




\begin{tabular}{ll}
\hline Level & \multicolumn{1}{c}{ Characters } \\
\hline 6. At this time, children like to form peer groups, \\
usually to play together
\end{tabular}

Source: Notoatmodjo (2012)

Based on elementary school students' intellectual development and character, it is very good to instill good values in everyday life. One of which is the cultivation of religious moderation as an initial effort to form an attitude of tolerance for the differences they encounter later in society. The realization or efforts to inculcate religious moderation in elementary schools can be made using an approach in character education, including:

\section{a. Inculcation Approach}

The theory states that an inculcation approach is an approach that emphasizes the cultivation of values into students (Zafi, 2020: 28). This approach teaches values in the learning process, social values, religion, tolerance, and various understandings that lead to good values that will form good morals in each student. Values inculcation in this learning process prioritizes exemplary methods, simulations, and role models to provide real examples for students. The formation of student tolerance can certainly be through an approach to teaching the value of religious moderation in each student, giving students an understanding to behave in a balanced (neutral) manner without seeing differences and respecting differences in beliefs. Teaching the value of religious moderation is certainly one of the teacher's efforts to form a tolerant attitude of students.

This value-instilling approach prepares students to become better human beings. Several experts have expressed that value-instilling is an effort to humanize humans. Windrati (2011: 46) stated that value education is humanizing humans so that values education has an important position within oneself human.

The value inculcation approach is a process that aims to reach the stage where students have good character. However, this value inculcation approach goes through a long process to arrive at being united in students. The stages described by Muhaimin in Shodiq (2017: 17) are as follows: (1) value transformation stage, (2) value transaction stage, and (3) value trans-internalization. From the first stage, starting from the transformation of values, the teacher provides value implants based on verbal information. In this case, the course transfers understanding related to religious moderation and how we display attitudes when dealing with people with different beliefs. Then, the next stage is the value transaction carried out in two directions or reciprocity between teachers and students. The teacher is not only limited to transferring values verbally, but more than that, the teacher gives real examples of good attitudes. Students respond in the form of accepting and practicing in their daily lives. The last stage is trans-internalization that what is displayed is no longer just an example of a mere figure but has become a character and personality in a person.

b. Cognitive Moral Development Approach

The cognitive moral development approach emphasizes cognitive aspects and their development. This approach encourages students to think about moral problems and make decisions. The characteristic of this approach is the development of thinking (cognitive) which shapes thinking in making decisions based on moral considerations so that behavior that arises is based on students' arguments against various selected considerations. This approach trains students to think systematically in dealing with problems in their lives. 
Moral learning in the concept's view of cognitive development emphasizes the role of the teacher to discuss moral problems that will be taught in the formal curriculum. Teachers are expected to take advantage of hypothetical moral situations (seeing problems from various perspectives) or sociological situations. It is in line with national education goals to develop their potential, have a good religious level, selfcontrol, and noble character, which is illustrated by attitudes in their daily lives.

Moral development is correlated with the development of intelligence so that if intelligence experiences a level of maturity, it will also be accompanied by moral maturity. Therefore, during this period of moral development, teachers need to instill good character and develop students' potential to think and consider things in decision making. Thus, this cognitive moral approach makes students better understand the problems from simple to complex aspects. Finding solutions is seen from various problems according to the situation and conditions (Shodiq, 2017: 20).

c. Values Analysis Approach

The value analysis approach emphasizes the development of student's abilities so that they can think logically by analyzing a problem related to social values. Compared to the cognitive moral process, this approach is more focused on social values in discussing the problem. One of which is analyzing the issue of intolerance in a pluralistic society by providing the value of tolerance in religious moderation. Murniati (2011: 204) explained that value analysis is a learning approach that aims to provide several ways to help students think logically in choosing values.

This approach is beneficial for students to find the values behind the behavior that appears. This value analysis approach emphasizes discussing a problem that contains social values. Therefore, the problem included in the issue of religious moderation has social values when viewed from this value analysis approach because it departs from a problem, namely pluralism. The cultivation of religious moderation values gives rise to attitude values, one of which is tolerance.

The value analysis approach is an effort to develop values with three stages in the learning process. The first is the introduction of environmental facts. The second is the stage of forming a concept. At this stage, students are faced with thinking in their cognitive structure based on the knowledge obtained from the theory they have learned and connected with the facts they discovered earlier. The third stage is the stage of taking values based on integrated considerations. This value analysis approach is needed to achieve these stages properly.

d. Value Clarification Approach

A value clarification approach is an approach that trains students' skills in the process of assessing various aspects of events in everyday life (Istati, 2018: 281). This approach helps to have awareness and identify their values and the values of others. This approach also enables students to communicate honestly and relate to others through their values. This approach emphasizes how students can form and build values that they think are good so that these values are explored as to their daily attitudes.

The value clarification approach in the learning process aims to find and determine a good value by analyzing the values that already exist, which cannot be separated from thinking, feeling, choosing, communicating, and application (acting). In the learning process, this approach helps students find a good value by analyzing values that already exist, and students are fostered by their emotional awareness.

The value clarification approach aims to instill a good value into students, increase awareness of good attitudes in each individual, and provide guidance on 
positive and negative matters. Students are directed to improve their attitudes to find out how they are aware of the character's value (Muhammad, Reinita, \& Fitria, 2020: 1483). e. Action Learning Approach

An action learning approach is an approach that emphasizes efforts to provide opportunities for students to act and instill morals. Superka in Anjani (2018: 17) explained that there are two main objectives of moral education based on the action learning approach, namely, providing opportunities for students to perform moral actions both independently and in groups, and encouraging students to see themselves as individual beings and social beings in the association of daily life. The form in this approach is done through providing opportunities for students to do good morals based on their values. Overall, this approach can be seen in the following figure:

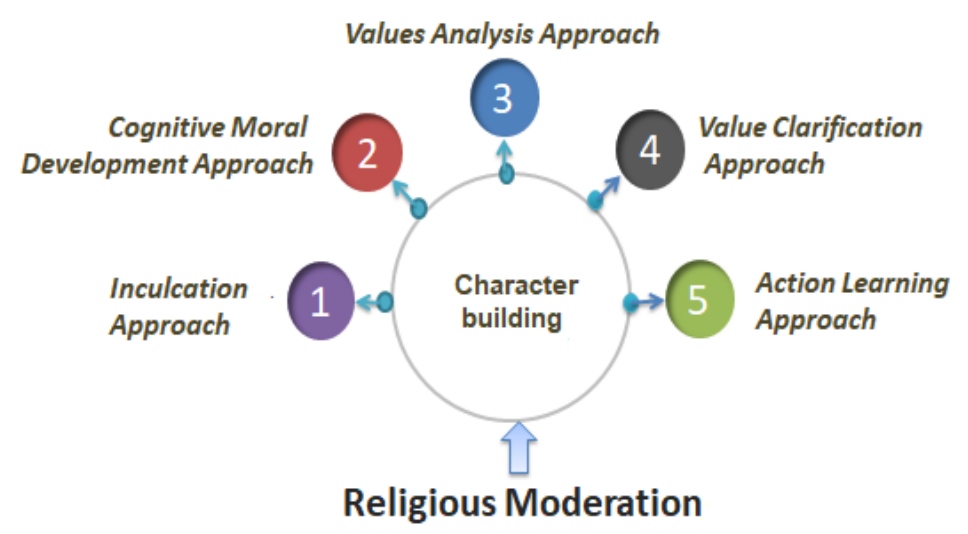

Figure 1. Implementation of Religious Moderation in Character Education

By implementing religious moderation through character education (value inculcation approach, cognitive moral development approach, value analysis approach, value clarification approach, and learning approach to action) will form student tolerance attitudes, namely:

a. Religious Tolerance

Religion is a form of a person's belief that comes from his/her conscience, not formed by coercion. Religion becomes a person's belief, so we have no right to judge. On the contrary, we must respect what has become someone's belief; this is called religious tolerance. Religious tolerance is an attitude or behavior in respecting and appreciating other religious groups or those with other beliefs.

b. Thought Tolerance

Each individual must have a different character and pattern of thinking. It is something human that does not need to debate in life. As someone who has understood the deep meaning of an attitude of tolerance, he/she will apply it in his/her daily life not to make differences into debates or divisions. Tolerance of this thinking is a person's attitude to accept differences to what he/she believes.

c. Social Tolerance

This social tolerance refers to social life because everyone must have a different social class. Historically, many cases of intolerance have occurred because of the lack of tolerance, which is also called intolerance. Inculcating the value of religious moderation can form an attitude of tolerance and live properly, not seeing other people from social status. 


\section{d. Racial Tolerance}

Racial tolerance is tolerance related to different ethnicities or tastes. Because Indonesia is a pluralistic country, it will face people of different ethnicities, ethnicities, and races. The attitude of tolerance will make these differences harmonious in everyday life.

Not only through these approaches, realizing religious moderation in education as the formation of student tolerance can also be done with:

a. Teaching Materials Based on integrating Religious Moderation

Teaching materials are all learning resources that have been systematically and structured to answer learning objectives. Teaching materials in the learning process will affect the learning atmosphere and learning outcomes. Teaching materials are various kinds of materials used by teachers to assist and facilitate the implementation of the learning process, both written and unwritten.

Aziz \& Najmudin (2020: 99) said that teaching materials were made in written form, such as books, modules, worksheets, handouts, wallchart brochures. The forms of unwritten teaching materials are videos/films, VCD, radios, cassettes, and internetbased interactive CDs. With the various teaching materials, teachers can develop them by integrating something that they want to measure and improve students. One example is the development of visual teaching materials carried out by Marthandini \& Anshori (2020) with the title "Pengembangan Media Ajar Visual Meme Berbasis Moderasi Islam pada Mata Pelajaran Fiqih Kelas VIII di MTs Salafiyah Syatiiyah Seblak”.

If the understanding of religious moderation is applied through various approaches to implementing value education, Amril (2021: 77) explained that value education is a conscious effort in education that contributes to fostering actual moral values and behavior. Teaching materials also have an important role in instilling the values of religious moderation. In the education aspect, a teaching material must be designed to strengthen the cultivation of religious moderation. The Minister of Religion of the Republic of Indonesia, Qoumas in Fahlevi (2021), explained that in the education aspect, educators and education administrators should develop teaching materials that strengthen the implementation of religious moderation.

In developing teaching materials, the teacher must pay attention to various considerations, including (1) accuracy of content, how the content contains all the needs that exist in the learning objectives, (2) accuracy of coverage, so that the discussion is focused and does not get out of the topic and the integrity of the concept according to science, (3) digestibility, teaching materials can be understood and digested by students, (4) use of language that students easily understand, (5) attractive illustrations, (6) packaging, and (7) completeness of components (Sitohang, 2014: 20-21).

b. Moderate Educator

Educators are often referred to as teachers, where educators are an essential learning component. Being an educator must have some characteristics that students can imitate. Creating a learning atmosphere and inculcating values in the learning process is very important for the exploration and development of values by students, so the role model of educators (awareness of the value of educators) is one factor that is needed (Rachman, 2019: 24). Teachers as educators certainly have a role as an example, and a teacher guides the flow of the learning process. Thus, a teacher must have characteristics and qualifications so that those who become educators are people who have been chosen. 
The qualifications of a teacher in teaching are divided into three parts of competence, which are related to mastery of teaching plans, teaching procedures, and interpersonal relationships (Jahidi, 2014: 24). Hamalik in Samuji (2021: 51) also explained that a professional teacher has several requirements: having talent as a teacher, having expertise as a teacher, having good and integrated skills, having a healthy mentality, extensive experience, and knowledge. A teacher is tasked with providing knowledge to students and forming character to become a superior, independent person who can practice the knowledge (Samsul, 2020: 43).

Besides qualifications in these fields, in facing our condition in this diverse country, an educator is equipped with an understanding of religious moderation because Indonesia is a diverse country, so the task and role of the teacher are to instill a high value of tolerance in students through religious moderation. Because of this, teachers must be equipped with an understanding of religious moderation through training, seminars, etc. These various efforts can provide students to have a high tolerance attitude. It is also related to the results of research conducted by Akbar (2020: 136), which found that one role of teachers in building religious moderation is a transmitter, namely transmitting moderation values to students.

\section{Conclusion}

Religious moderation is an attitude that every individual must own in dealing with existing differences in terms of belief, ethnicity, lifestyle, and others. The attitude of religious moderation reflects the behavior of a person who is not inclined to a party, giving birth to an attitude of tolerance, and avoiding division. The cultivation of the value of religious moderation needs to be socialized to every element of society to create harmony and tolerance for others. Not only socialization to the community but also be realized in the world of education, and this becomes an appropriate forum for developing student attitudes. The realization that is carried out in the world of education should be at the university level and start from elementary school so that student tolerance can be formed from an early age. We can realize this religious moderation as character education through a value inculcation approach, a cognitive moral development approach, a value analysis approach, a value clarification approach, and a learning approach to action. Realizing religious moderation in education requires teaching materials to integrate religious moderation and moderate educators. In this way, student tolerance will be formed, namely religious tolerance, thought tolerance, social tolerance, and racial tolerance in elementary school students.

\section{References}

Akbar, A. (2020). Peran Guru PAI dalam Membangun Moderasi Beragama di SDN Beriwit 4 SDN Danau Usung 1 Kabupaten Murung Raya. Institut Agama Islam Negeri Palangka Raya.

Akhmadi, A. (2019). Moderasi Beragama dalam Keragaman Indonesia. Jurnal Diklat Keagamaan, 13(2), 45-55. https://bdksurabaya.e-journal.id/bdksurabaya/article/ view/82

Alganih, I. (2016). Konflik Poso (Kajian Historis Tahun 1998-2001). Criksetra: Jurnal Pendidikan Sejarah, 5(2), 166-174. https://doi.org/10.36706/JC.V5I2.4814

Alhendi, O. (2021). Cultural Diversity, Intercultural Competence, Tolerance, and the Economy: A Review. International Journal of Engineering and Management 
Sciences (IJEMS), 6(2), 98-109. https://doi.org/10.21791/IJEMS.2021.2.9

Amran, M., Sahabuddin, E. S., \& Muslimin. (2018). Peran Pendidikan Karakter di Sekolah Dasar. Prosiding Seminar Nasional Administrasi Pendidikan \& Manajemen Pendidikan, 254-261. https://ojs.unm.ac.id/semapfip/article/view/ 6121

Amril, M. (2021). Pendidikan Nilai Akhlak Telaah Epistimologi dan Metodologis Pembelajaran di Sekolah. PT Raja Grafindo Persada.

Anjani, S. R. (2018). Penerapan Model Pembelajaran Nilai (Value Learning) melalui Pendekatan Pembelajaran Berbuat (Action Learning Approach). Jurnal Koulutus: Jurnal Pendidikan Kahuripan, 1(1), 11-34. https://ejournal.kahur ipan.ac.id/index.php/koulutus/article/view/68

Aziz, A., \& Najmudin, N. (2020). Moderasi Beragama dalam Bahan Ajar Mata Kuliah Pendidikan Agama Islam (PAI) di Perguruan Tinggi Umum Swasta (Studi di STIE Putra Perdana Indonsesia Tangerang). Jurnal Pendidikan Karakter JAWARA (Jujur, Adil, Wibawa, Amanah, Religius, Akuntabel), 6(2), 95-117. https://jurnal.untirta.ac.id/index.php/JAWARA/article/view/9778

Fahlevi, F. (2021). Menteri Agama: Bahan Ajar dapat Memperkuat Moderasi Beragama. Tribunnews.Com. https://www.tribunnews.com/nasional/2021/03/ 27/menteri-agama-bahan-ajar-dapat-memperkuat-moderasi-beragama

Istati, M. (2018). Pendekatan Klarifikasi Nilai untuk Mengembangkan Karakter Anak melalui Layanan Bimbingan dan Konseling di Sekolah Dasar/Madrasah Ibtidaiyah. Seminar Nasional Pendidikan Banjarmasin, 280-286. http://snpfm otogpe.ulm.ac.id/proceeding/index.php/snpf/article/view/20

Jahidi, J. (2014). Kualifikasi dan Kompetensi Guru. Administrasi Pendidikan: Jurnal Ilmiah Mahasiswa Pascasarjana, 2(1), 23-30. https://jurnal.unigal.ac.id/index. php/adpen/article/view/189

Marthandini, N. M., \& Anshori, S. (2020). Pengembangan Media Ajar Visual Meme Berbasis Moderasi Islam pada Mata Pelajaran Fiqih Kelas VIII di MTS Salafiyah Syafiiyah Seblak. Jurnal Pendidikan Islam Al-Ilmi, 3(1), 48-57. https://doi.org/10.32529/AL-ILMI.V3I1.369

Muhammad, M., Reinita, \& Fitria, Y. (2020). Pendekatan Value Clarification Technique dalam Pendidikan Karakter di Sekolah Dasar. Jurnal Pendidikan Tambusai, 4(2), 1480-1493. https://doi.org/10.31004/jptam.v4i2.614

Murniati, B. (2011). Pengaruh Pendekatan Analisis Nilai dalam Pembelajaran IPA terhadap Sikap Kepedulian Sosial Peserta Didik. Edisi Khusus, 2, 201-212. http://jurnal.upi.edu/file/20-Baiq_Murniati-edit.pdf

Ndolu, N. N., \& Tari, E. (2020). Religious Tolerance Based on Ezra 5-6. Biblical Theology Bulletin: Journal of Bible and Culture, 50(2), 77-82. https://doi.org/ $10.1177 / 0146107920913792$

Notoatmodjo, S. (2012). Metodologi Penelitian Kesehatan. Rineka Cipta.

Rachman, B. M. (2019). Pendidikan Karakter dengan Pendekatan Living Values Education. The Asia Foundation.

Samsul, A. R. (2020). Peran Guru Agama dalam Menanamkan Moderasi Beragama. AlIrfan: Journal of Arabic Literature and Islamic Studies, 3(1), 37-51. https://doi. org/10.36835/AL-IRFAN.V3I1.3715

Samuji. (2021). Mengenal Persyaratan Pendidik bagi Guru dalam Upaya Mencapai Tujuan Pendidikan Islam. Jurnal Paradigma, 11(1), 45-63. https://doi.org/ 10.53961/JURNALPARADIGMA.V11I01.101 
Sari, M., \& Asmendri. (2020). Penelitian Kepustakaan (Library Research) dalam Penelitian Pendidikan IPA. Natural Science: Jurnal Penelitian Bidang IPA dan Pendidikan IPA, 6(1), 41-45. https://doi.org/10.15548/nsc.v6i1.1555

Shodiq, S. F. (2017). Pendidikan Karakter melalui Pendekatan Penanaman Nilai dan Pendekatan Perkembangan Moral Kognitif. Jurnal At-Tajdid, 1(1), 14-25. https://doi.org/10.24127/att.v1i01.332

Sitohang, R. (2014). Mengembangkan Bahan Ajar dalam Pembelajaran Ilmu Pengetahuan Sosial (IPS) di SD. Jurnal Pendidikan Pancasila dan Kewarganegaraan, 23(2), 13-24. http://digilib.unimed.ac.id/id/eprint/1457

Sudarmawan. (2013). Hubungan antara Pengetahuan dan Sikap Mengenai Pemilihan Jajanan dengan Perilaku Anak Memilih Jajan di SDN Sambikerep II/480 Surabaya. Jurnal Pendidikan Olahraga dan Kesehatan, 1(1). https://adoc.pub/ 480-surabaya-artikel.html

Supriyanto, A., \& Wahyudi, A. (2017). Skala Karakter Toleransi: Konsep dan Operasional Aspek Kedamaian, Menghargai Perbedaan, dan Kesadaran Individu. Jurnal Ilmiah Counsellia, 7(2), 61-70. https://doi.org/10.25273/coun sellia.v7i2.1710

Sutrisno, E. (2019). Aktualisai Moderasi Beragama di Lembaga Pendidikan. Jurnal Bimas Islam, 12(2), 324-348. https://doi.org/10.37302/jbi.v12i2.113

Windrati, D. K. (2011). Pendidikan Nilai Sebagai Suatu Strategi dalam Pembentukan Kepribadian Siswa. Jurnal Formatif, 1(1), 40-47. https://doi.org/10.30998/ formatif.v1i1.60

Zafi, A. A. (2020). Penerapan Nilai-nilai Moderasi Al-Qur'an dalam Pendidikan Islam. Jurnal Studi Al-Qur'an dan Hadis, 21(1), 23-46. https://doi.org/10.14421/ qh.2020.2101-02 